\title{
Isabelle Daunais, De «ceci» à «celà»: les Illuminations de Flaubert
}

Isabella Giovinazzo

\section{Q OpenEdition}

\section{Edizione digitale}

URL: https://journals.openedition.org/studifrancesi/38007

DOI: 10.4000/studifrancesi.38007

ISSN: 2421-5856

\section{Editore}

Rosenberg \& Sellier

\section{Edizione cartacea}

Data di pubblicazione: 15 décembre 2004

Paginazione: 635

ISSN: 0039-2944

\section{Notizia bibliografica digitale}

Isabella Giovinazzo, «Isabelle Daunais, De «ceci» à «celà»: les Illuminations de Flaubert», Studi Francesi [Online], 144 (XLVIII | III) | 2004, online dal 30 novembre 2015, consultato il 08 mai 2021. URL: http:// journals.openedition.org/studifrancesi/38007 ; DOI: https://doi.org/10.4000/studifrancesi.38007

Questo documento è stato generato automaticamente il 8 mai 2021.

\section{(c) $(1) \&$}

Studi Francesi è distribuita con Licenza Creative Commons Attribuzione - Non commerciale - Non opere derivate 4.0 Internazionale. 


\title{
Isabelle Daunais, De «ceci» à «celà»: les Illuminations de Flaubert
}

\author{
Isabella Giovinazzo
}

\section{NOTIZIA}

ISABELLE DAUNAIS, De «ceci» à «celà»: les Illuminations de Flaubert, «Romantisme» n. 115 (I

Trim 2002) pp. 5-12.

1 Nonostante la nota opposizione alle illustrazioni all'interno delle sue opere, per un'edizione di lusso di La Légende de saint Julien l'Hospitalier, Flaubert aveva scelto di inserire la riproduzione di un disegno della vetrata della cattedrale di Rouen. I motivi della singolare scelta dipendono dall'estraneità tra il racconto e il disegno, oltre che dal suo valore di documento storico, quindi totalmente indipendente dal testo. In questa scelta si può dunque vedere, secondo l'A., una sorta di riflesso delle modalità stesse della scrittura flaubertiana e della sua problematicità, della sua costante oscillazione tra espansione e conclusione, tra enigma e rivelazione che mantiene il racconto ad uno stato incompiuto e lascia nel lettore l'impressione di una costante ambiguità. 